\title{
ANALYSIS OF STRESS IN STEEL AND CONCRETE IN CFST PUSH-OUT TEST SAMPLES
}

\author{
Bartosz GRZESZYKOWSKI*, Magdalena SZADKOWSKA, \\ Elżbieta SZMIGIERA \\ Warsaw University of Technology, Warszawa, Poland
}

\begin{abstract}
The paper presents the analysis of stress in steel and concrete in CFST composite elements subjected to push-out tests. Two analytical models of stress distribution are presented. The bond at the interface between steel and concrete in the initial phase of the push-out test is provided by the adhesion. Until the force reach a certain value, the slip between both materials does not occur or it is negligibly small, what ensures full composite action of the specimen. In the first analytical model the full bond between both materials was assumed. This model allows to estimate value of the force for which the local loss of adhesion in given cross section begins. In the second model it was assumed that the bond stress distribution is constant along the shear transfer length of the specimen. Based on that the formulas for triangle distribution of stress in steel and concrete for the maximum push-out force were derived and compared with the experimental results. Both models can be used to better understand the mechanisms of interaction between steel and concrete in composite steel-concrete columns.
\end{abstract}

Keywords: composite steel-concrete columns, CFST, bond stress, adhesion, push-out test

\footnotetext{
* Corresponding author: Warsaw University of Technology, Faculty of Civil Engineering, Armii Ludowej 16, 00-637 Warszawa, Poland, e-mail: b.grzeszykowsk@il.pw.edu.pl, tel.: +48228255758
} 


\section{INTRODUCTION}

Ensuring a full composite action in composite steel concrete elements is very beneficial both from the economic and mechanical point of view. For composite elements subjected to bending provision of connectors at the interface of steel and concrete is obligatory. However in elements under compression connection between steel and concrete can, according to [3], be achieved by the natural bond between these materials provided that the surface of the steel section in contact with the concrete is unpainted and free from oil, grease and loose scale or rust. Shear connectors should be provided, based on the distribution of the design value of longitudinal shear $\tau_{E d}$, where this exceeds the design shear strength $\tau_{R d}$.

In the world literature the research on the influence of various parameters such as: type of the column, transverse and longitudinal dimesions, type and strength of concrete and its rheological properties on bond strength between steel and concrete can be found [1,7].

In $[4,5]$ Hunaiti presented results of the research of bond conditions in selected type of two-chord composite columns. Tested members were $300 \mathrm{~mm}$ high and consisted of two battened $\mathrm{C}$ profiles filled with concrete. The variable parameters were: the geometry of cross sections, grade of concrete and time at which the tests were conducted. The most important conclusion of these papers is that the bond between steel and concrete largely depends on the type of composite cross section. Moreover, the shrinkage of concrete largely influences bond conditions, because vertical shear resistance for tested members after 360 days was around $30 \%$ of the value obtained after 21 days from filling with concrete. The bond between steel and concrete in composite two chord battened columns was the subject of the research made by Szmigiera and Woyciechowski in [9] and Szmigiera et al. in [10]. The authors investigated two battened HEA 160 section filled with self compacting concrete (SCC) and concluded that the resistance to the vertical shear increases with the increase of the cylinder compressive strength of SCC but the relationship is not proportional, the total shrinkage of SCC negatively affects its bond between the materials and the use of SCC have a detrimental influence on steel-concrete bond in comparison with the traditional vibrated concrete.

Virdi and Dowling [11,12] investigated bond properties of circular CFST elements using push-out tests. Typical global response of the push-out test specimen, where $s$ is the slip defined as the difference between displacements of concrete and steel, and $N$ is the push-out load is presented in Fig. 1a. The authors concluded that the most important factor contributing to the behavior of specimens is the mechanical keying of the concrete core with irregularities in the steel tube. According to [11,12] the bond behavior between steel and concrete can be considered as an outcome of three different mechanisms (Fig. 1a): adhesion, microlocking and macrolocking. Adhesion is caused by the natural adherence 
between steel and concrete and is aided by the static friction. The force $N_{b, g l}$ determined from the force - slip curve (Fig. 1) is the force for which the loss of adhesion and slip begins. This is a global response of the push-out test specimen, thus the force determined in this way is the result of integration of the vertical shear stress over the entire transfer length of the sample. Until the push-out force reach the value $N_{b, g}$, the slip between both materials does not occur or is negligibly small, what ensures full composite action of the specimen.

Microlocking is related to the surface roughness of steel. The macrolocking becomes active when the microlocking is broken - the concrete core begins to move as a rigid body and the large scale system of kinetic friction begins and continues until the maximum global slip $s_{\max , g l}$ is reached. This type of bond resistance occurs due to the manufacturing tolerances associated with the internal diameter of the tube and contributes in essence to the frictional resistance associated to the post-peak part of the push-out load versus slip response [11,12]. Local bond action in composite steel-concrete members is represented by the bond stress - slip relationship presented in Fig. 1b. The ultimate shear stress, $\tau_{U}$, can be determined from the push-out test. The bond stress for which the loss of adhesion begins is represented by $\tau_{b}$ and the determination of this value is not the subject of this paper.
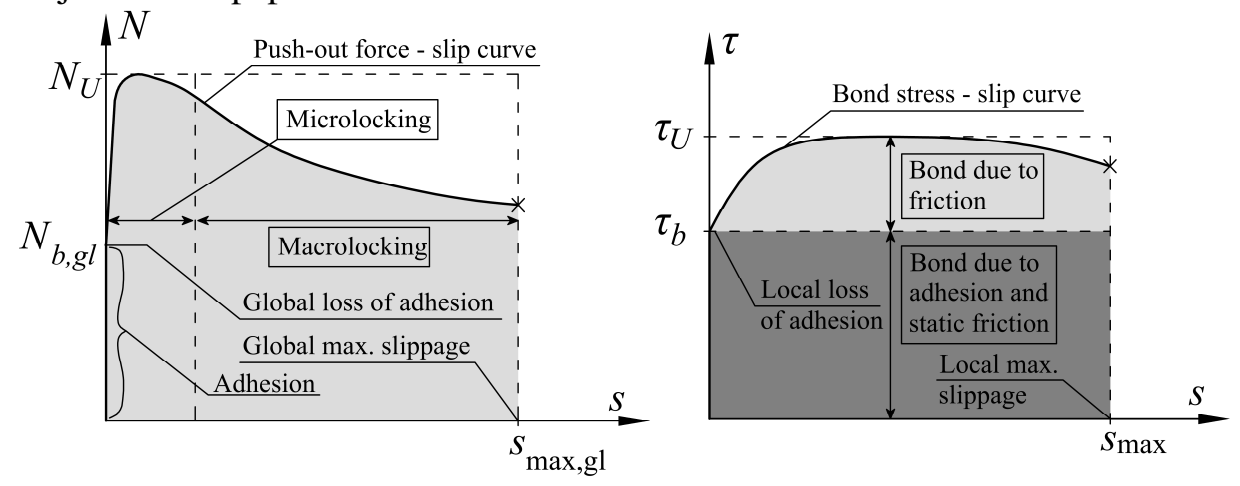

Fig. 1. a) Global response of the push-out test element;

b) Bond stress - slip relationship

Roeder et al. [8] conducted push-out tests of relatively long circular CFST elements with particular focus on the phenomenon of shrinkage in concrete. The $H / D$ ratios varied from 2.9 to 5.1 and $D / t$ ratios varied from approximately 0.01 to 0.05 , where $H, D, t$ is the length, diameter and wall thickness of tubes respectively. The 28 day target concrete strength was $51 \mathrm{MPa}$. In author's opinion the bond strength in tested members decreases as the $D / t$ increases or as the diameter of the tube decreases. Moreover he concluded that the slip between steel and concrete did not occur until the applied force reached 40 to $80 \%$ of the 
ultimate, and the ultimate load was achieved at slip displacements between 20 and 200 times larger than the initial breakaway slip. For slip greater than that at the ultimate load, the behavior was of rigid body motion between the core and the tube with reducing mechanical resistance from interface shear (macrolocking). Moreover authors concluded that when the interface condition allowed zero slip, the bond stress was exponentially distributed. The value was a maximum at the end of the interface where the loading was applied. After slip occurred and propagated down the tube, a more uniform distribution developed.

In [6] Ke studied the bond strength in steel tubes filled with high-strength concrete. He conducted push out tests of specimens with $H / D$ ratio equal to 3.6, filled with three types of concrete: $\mathrm{C} 60, \mathrm{C} 70, \mathrm{C} 80$. He concluded that the interface slip between steel tube and concrete can be divided into no slip, local slip and whole slip, which is a process gradual accumulation of slip damage. Moreover from the analysis of the load - slip curves the author found out that the slip at the loaded end is the very early appearing, that is, the development of the interface bond failure is from the loaded end to free end of tested specimens and both $N_{b, g l}$ and $s_{\max , g l}$ measured on the loaded end of the push-out test sample may vary from measurements taken at the free end.

In this paper the authors focused more on analytical analysis of bond behaviour at the interface between steel and concrete. Two analytical models describing the behaviour of steel and concrete in the initial phase of the push-out test, when the adhesive bond ensures full composite action of specimens, and when the push-out force reaches the maximum value, $N=N_{U}$, are presented in the following paragraphs of this work. Analytical calculations were compared with the experimental results of push out tests of steel tubes filled with SCC conducted by the authors.

\section{EXPERIMENTAL RESEARCH}

Most of the experiments on bond stress capacity for composite steel concrete columns are conducted using push-out tests. For CFST elements this experiment consists of applying the compressive force only to concrete pushing the concrete inside the steel tube. The air gap on the free end of specimen is necessary to transfer the entire force from concrete to steel jacket only by longitudinal shear. Push-out tests conducted by the authors were performed on circular and square CFST elements made of S235JR steel. The shear transfer length was equal 300 $\mathrm{mm}$. Variable parameters were: wall thickness for square specimens $(6 \mathrm{~mm}$ and $10 \mathrm{~mm}$ ) and concrete class for circular tubes. A total number of 11 elements that exhibit consistent behaviour was investigated. Dimensions of the cross section of both square and circular tubes were chosen so that the area of steel in contact with concrete core to be approximately equal. Table 1 lists a detailed description of the 
material and geometrical properties. The table columns contain, respectively, the notation of the series; type of a cross section, concrete strength and the area of contact surface between steel and concrete. For easier interpretation of the test variables, all cross sections considered in the experiment are visualized in Figure 2.

Table 1. Analysed cross section types

\begin{tabular}{|c|c|c|c|}
\hline $\begin{array}{c}\text { Notation of } \\
\text { series }\end{array}$ & Cross section type & $f_{\text {cm,cube }}[\mathrm{MPa}]$ & Contact surface $\rho\left[\mathrm{cm}^{2}\right]$ \\
\hline STS & SHS180x180x6 & 57 & 2016 \\
\hline STHS & SHS180x180x10 & 57 & 1920 \\
\hline CS & CHS219.1x6 & 57 & 1952 \\
\hline CWk & CHS219.1x6 & 44 & 1952 \\
\hline
\end{tabular}
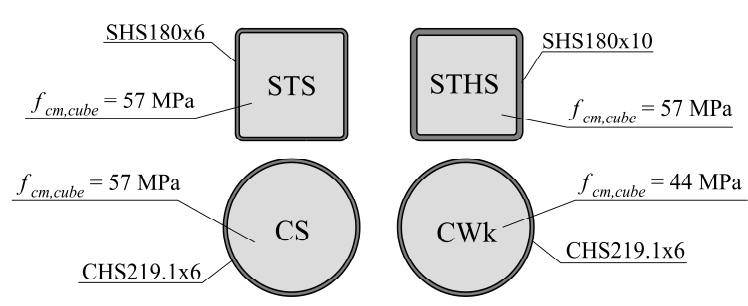

Fig. 2. Element types analysed in the paper

In every specimen concrete core was protruded from the top of the steel sections and subjected to axial compression in a discplacement controlled hydraulic press down to failure. Both vertical and horizontal strains of steel profiles were measured in the mid-heigth of specimens using strain gauges (see Fig. 3a). Placement of strain gauges and the view of the experimental testing setup can be seen in Fig. 3a and 3b.

a)

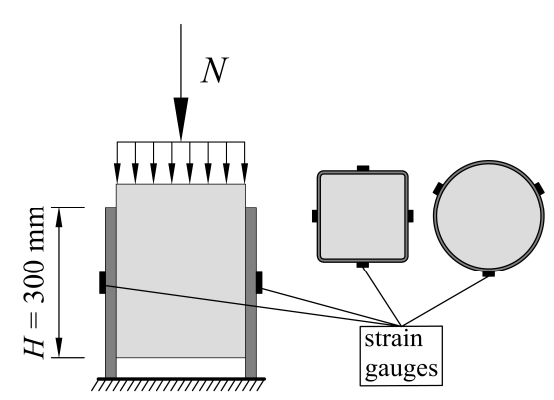

b)

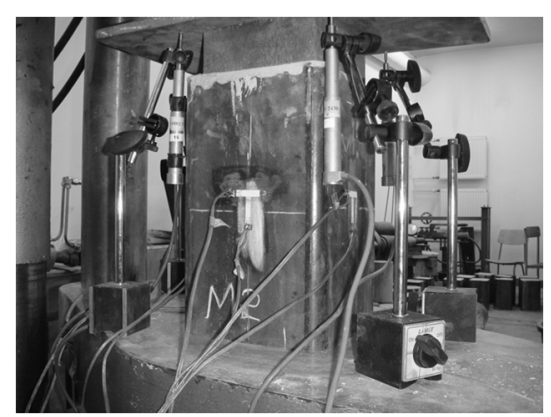

Fig. 3. a) Scheme of the test stand and visualization of strain gauges placement, b) SHS specimen under the push-out test 


\section{ANALYTICAL MODELS}

\subsection{Full bond linear model}

Let the force for which the local loss of adhesion in a given cross section begins be called $N_{b}$. The full bond linear model described in the following paragraph allows one to estimate the value of $N_{b}$ at any cross section where the longitudinal strains of steel are measured.

The loads usually achieved in the push-out tests are very often far below the loads necessary to yield either steel or concrete, therefore stress in steel and concrete parts of the cross section, assuming Hooke's law for both materials, can be computed as follows

$$
\begin{gathered}
\sigma_{s}=E_{s} \varepsilon_{s} \\
\sigma_{c}=E_{c} \varepsilon_{c}
\end{gathered}
$$

where: $E_{s}, E_{c}$ - Young's moduli of steel and concrete respectively,

$\varepsilon_{s}, \varepsilon_{c}$ - longitudinal strain of steel and concrete respectively.

The forces transferred through the steel and concrete only are equal

$$
\left\{\begin{array}{l}
N_{s}=A_{s} \sigma_{s}=A_{s} E_{s} \varepsilon_{s} \\
N_{c}=A_{c} \sigma_{c}=A_{c} E_{c} \varepsilon_{c}
\end{array}\right.
$$

where: $A_{s}, A_{c}$ - area of cross section of steel and concrete respectively. Introducing eq. (3.1), (3.2) and (3.3) into the global equilibrium equation

$$
N=A_{s} \sigma_{s}+A_{c} \sigma_{c}
$$

and assuming the perfect bond between steel and concrete: $\varepsilon=\varepsilon_{s}=\varepsilon_{c}$, the linear solution of the evolution of stress in steel and concrete can be written as follows

$$
\begin{aligned}
& \sigma_{s}(N)=\frac{\alpha}{\alpha A_{s}+A_{c}} N \\
& \sigma_{c}(N)=\frac{1}{\alpha A_{s}+A_{c}} N
\end{aligned}
$$

where: $\alpha=E_{s} / E_{c}$. 
In the experiment the longitudinal strains of steel profiles in the mid-heigth $\varepsilon_{s}$ were measured, therefore the analytical solution can be compared to results obtained from the experiment. The force transferred through the steel only is equal

$$
N_{s}=A_{s} E_{s} \varepsilon_{s}
$$

The force transferred through concrete can be computed as a difference of the total acting force $N$ and the force transferred through the steel only

$$
N_{c}=N-N_{s}
$$

The evolution of stress in steel in a given cross section where the strain was measured can be computed according to eq. (3.1) and stress in concrete core can be computed as follows

$$
\sigma_{c}(N)=\frac{N}{A_{c}}-\frac{A_{s}}{A_{c}} E_{s} \varepsilon_{s}
$$

Stress in a given cross section computed according to the full bond model, eqs. (3.5) and (3.6), can be compared with results from the experiment, eqs. (3.1) and (3.9), therefore the stress in steel and concrete and the force at which the loss of adhesion begins can be estimated.

\subsection{Perfectly plastic model}

The second analytical model describing the distribution of stress in steel and concrete for the ultimate load $N=N_{U}$ is presented in the following paragraph. The perfectly plastic solution is correct only for the ultimate limit state of the pushout test sample and is valid for the assumed maximum force $N=N_{U}$. In this state the plastic zone covers the entire transfer length $H$. Assuming the constant distribution of shear stress $\tau_{U}$ along $H$ (Fig 4), the shear strength can be computed according to well known equation

$$
\tau_{U}=\frac{N_{U}}{\rho H}
$$

where: $N_{U}$ - maximum load, $\rho$ - perimeter of the concrete in contact with the steel tube, $H$ - length of the interface between steel and concrete. 


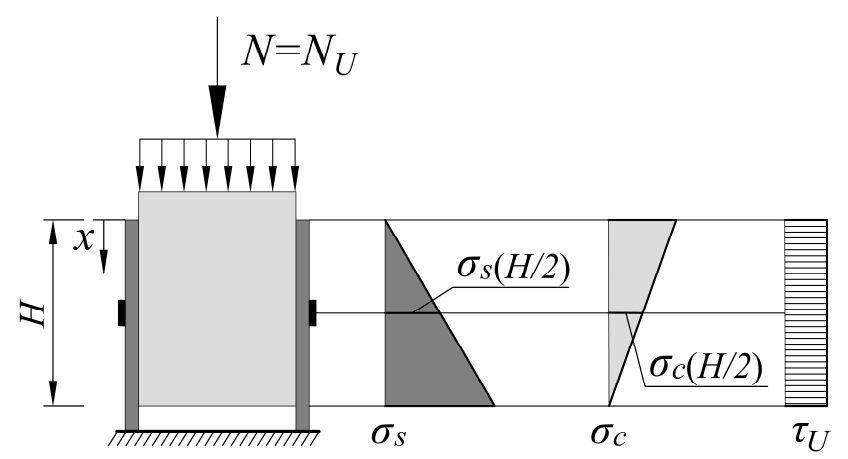

Fig. 4. Stress distribution along the height of the interface length $H$ in steel, concrete and at the interface between the materials in the ultimate limit state

The axial load gradients are related by statics to the interface bond stress distribution [8]. From the analysis of the infinitesimal cross section of the tube at the distance $x$ from the loaded end presented in Fig. 5, a system of ordinary differential equations was obtained

$$
\left\{\begin{array}{l}
\tau(x)=\frac{A_{s}}{\rho} \frac{d \sigma_{s}(x)}{d x} \\
\tau(x)=-\frac{A_{c}}{\rho} \frac{d \sigma_{c}(x)}{d x}
\end{array}\right.
$$

Eq. (3.11) connects the strain in steel and concrete with the bond stress on the interface between materials.

According to eq. (3.11) the derivatives of $\sigma_{s}(x)$ and $\sigma_{c}(x)$ are proportional to $\tau(x)$. Therefore assuming $\tau(x)=\tau_{b}=$ const., functions describing the distribution of stress in steel and concrete must be the linear with respect to $x$, hence

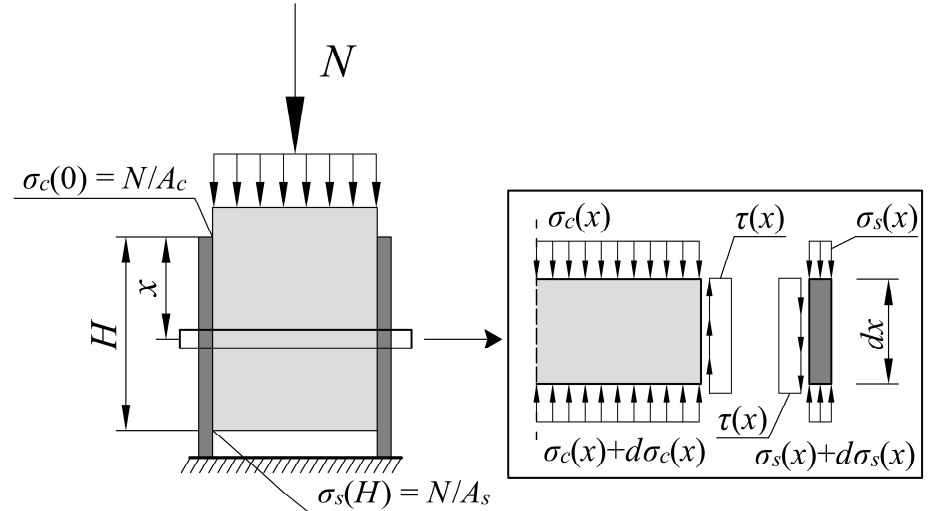

Fig. 5. Equilibrium of an infinitesimal cross section of push-out specimen 


$$
\left\{\begin{array}{l}
\sigma_{s}(x)=\frac{\rho}{A_{s}} \tau_{U} x+C_{1} \\
\sigma_{c}(x)=-\frac{\rho}{A_{c}} \tau_{U} x+C_{2}
\end{array}\right.
$$

The integration constants can be computed using the boundary conditions. Assuming $\sigma_{s}(0)=0$ and $\sigma_{c}(H)=0$ they are equal

$$
\left\{\begin{array}{l}
C_{1}=0 \\
C_{2}=\frac{H \rho}{A_{c}} \tau_{U}
\end{array}\right.
$$

The stress distribution in steel is equal

$$
\sigma_{s}(x)=\frac{\rho \tau_{U}}{A_{s}} x=\frac{N_{U}}{A_{s}} \frac{x}{H}
$$

and in concrete

$$
\sigma_{c}(x)=\frac{(H-x) \rho \tau_{U}}{A_{c}}=\frac{N_{U}}{A_{c}}\left(1-\frac{x}{H}\right)
$$

Finally the stress in steel and concrete in the mid-height of specimens $(x=H / 2)$ according to the perfectly plastic model equals

$$
\begin{gathered}
\sigma_{s}^{\mathrm{mod}}(H / 2)=\frac{N_{U}}{2 A_{s}} \\
\sigma_{c}^{\mathrm{mod}}(H / 2)=\frac{N_{U}}{2 A_{c}}
\end{gathered}
$$

The stress in steel and concrete according to the experiment, computed for the maxiumum force $N=N_{U}$, can be calculated using the following expressions

$$
\begin{gathered}
\sigma_{s}^{\exp }(H / 2)=E_{s} \varepsilon_{s U} \\
\sigma_{c}^{\exp }(H / 2)=\frac{N_{U}}{A_{c}}-\frac{A_{s}}{A_{c}} E_{s} \varepsilon_{s U}
\end{gathered}
$$


where: $\varepsilon_{S U}$ - longitudinal strain of steel measured in the experiment by strain gauges placed in the mid-height for $N=N_{U}$.

Results computed according to eq. (3.16), (3.17) and (3.18), (3.19) can be used to compare the perfectly plastic analytical model with the experiment and therefore to validate the model.

\section{RESULTS}

\subsection{Detection of the debonding force}

Measured in the experiment longitudinal strains of steel were implemented into the eqs. (3.1) and (3.9) and were compared with the perfect bond model according to eqs. (3.5) and (3.6). The results of the analysis are shown in Fig. 6, where $n=$ $N / N_{U}$ is the normalized acting force.

a)

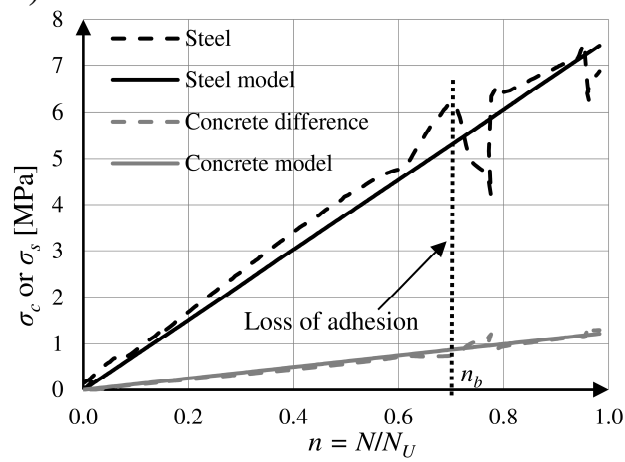

c)

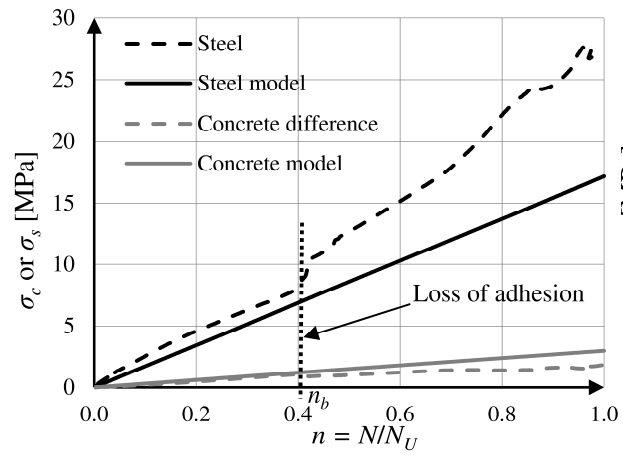

b)

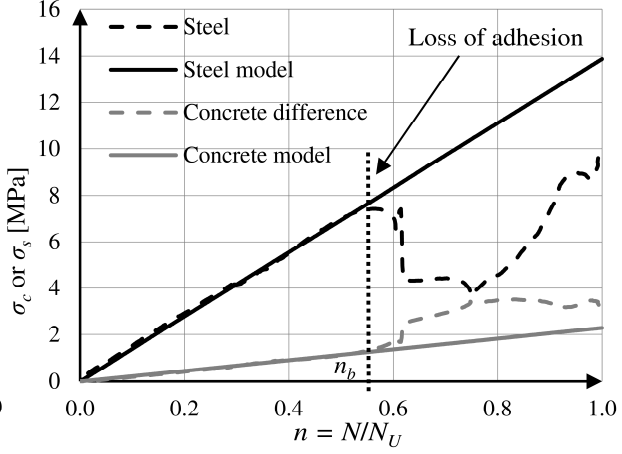

d)

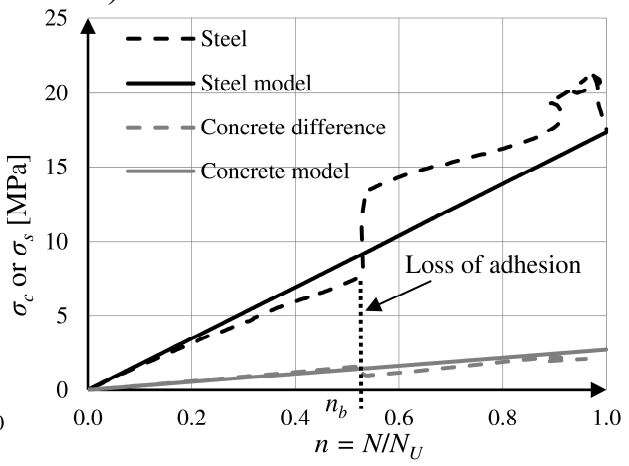

Fig. 6. Typical evolution of stress in steel and concrete in the mid-heigth of specimens for: a) STS, b) STHS, c) CS and d) CWk elements. Comparison of the experimental results and the analytical perfect bond model 
The dimensionless force $n_{b}=N_{b} / N_{U}$ for which the experimental results begin to deviate from the analytical full bond model can be interpreted, in the opinion of the authors, as the force for which the loss of adhesion begins. The range of the force $n_{b}$ on the basis of the above considerations for all tested specimens were gathered in the table 2. It can be seen that the loss of adhesion for square CFST specimens with thinner wall thickness, STS, occurs for higher relative force compared to the elements with thicker wall thickess, STHS. Filling the circular steel tubes with weaker concrete resulted in a decrease of the relative force at which the debonding occurs in relation to the stronger concrete filling.

Table 2. The force at which the adhesion bond breaks

\begin{tabular}{|c|c|}
\hline Series & $n_{b}$ \\
\hline STS & $0.50-0.70$ \\
\hline STHS & $0.40-0.55$ \\
\hline CS & $0.30-0.40$ \\
\hline CWk & $0.50-0.75$ \\
\hline
\end{tabular}

\subsection{Stress distribution for the maximum force}

Table 3 lists the results of the conducted analysis. The table columns contain, respectively, the type of the specimen; the ultimate force, $N_{U}$; the shear stress computed according to eq. (3.10), $\tau_{U}$; the stress in steel computed according to eqs. (3.16), $\sigma_{s}^{\bmod }(H / 2)$; and according to eq. (3.18), $\sigma_{s}{ }^{\exp }(H / 2)$; the stress in concrete computed according to eq. (3.17), $\sigma_{c}{ }^{\bmod }(H / 2)$; and according to eq. (3.19), $\sigma_{c}^{\exp }(H / 2)$. For easier interpretation of the provided data, the results gathered in table 3 were visualized in Fig. 7. It can be seen that values of stress in steel and concrete computed using perfectly plastic model coincide with values obtained from the experiment. It confirms the validity of the assumption used in the analysis that the distribution of the bond stress at the transfer length is approximately uniform for $N=N_{U}$.

Despite the fact that the elements STS, STHS and CS were filled with the same grade of concrete, the shear transfer area was approximately equal for all tested specimens and the STHS specimens have the thicker walls, the average shear strength $\tau_{U}$ obtained for circular tubes (specimens CS) is the largest. Filling the circular steel tubes with weaker concrete (specimens CWk) resulted in approximately $15 \%$ decrease in its shear strength and the stress in steel and concrete for the ultimate load. The maximum stress in steel in square CFST specimens with thicker walls, STHS, is almost two times greater compared to the elements with thinner walls, STS. The stress in concrete core is over 3 times greater. 
Table 3. The comparison of experimental research and analytical calculations

\begin{tabular}{|c|c|c|c|c|c|c|c|}
\hline Type & $\begin{array}{l}f_{\text {cm,cube }} \\
{[\mathrm{MPa}]}\end{array}$ & $\begin{array}{c}N_{U} \\
{[\mathrm{MPa}]}\end{array}$ & $\begin{array}{c}\tau_{U} \\
{[\mathrm{MPa}]}\end{array}$ & $\begin{array}{c}\sigma_{s}^{\bmod }(H / 2) \\
{[\mathrm{MPa}]}\end{array}$ & $\begin{array}{c}\sigma_{s}^{\exp }(H / 2) \\
{[\mathrm{MPa}]}\end{array}$ & $\begin{array}{c}\sigma_{c}{ }^{\bmod }(H / 2) \\
{[\mathrm{MPa}]}\end{array}$ & $\begin{array}{c}\sigma_{c}{ }^{\exp }(H / 2) \\
{[\mathrm{MPa}]}\end{array}$ \\
\hline 1 & 2 & 3 & 4 & 5 & 6 & 7 & 8 \\
\hline STS & 57 & 61 & 0.30 & 7.47 & 7.56 & 1.06 & 1.14 \\
\hline STHS & 57 & 171 & 0.89 & 13.24 & 13.40 & 3.34 & 3.27 \\
\hline $\mathrm{CS}$ & 57 & 196 & 1.01 & 24.45 & 24.88 & 2.92 & 2.87 \\
\hline CWk & 44 & 164 & 0.84 & 20.45 & 21.40 & 2.44 & 2.32 \\
\hline
\end{tabular}

In the opinion of the authors the assumption about the constant distribution of the bond stress for the ultimate load and therefore the validity of the shear strength results obtained using eq. (3.10) is correct provided that the height of the pushout test sample is not too large in relation to its transverse dimensions. This observation was confirmed on the basis of the analysis presented in this work carried out on relatively short specimens with $H / D=1.34$ for circular tubes and $H / D=1.67$ for square tubes.

a)

b)
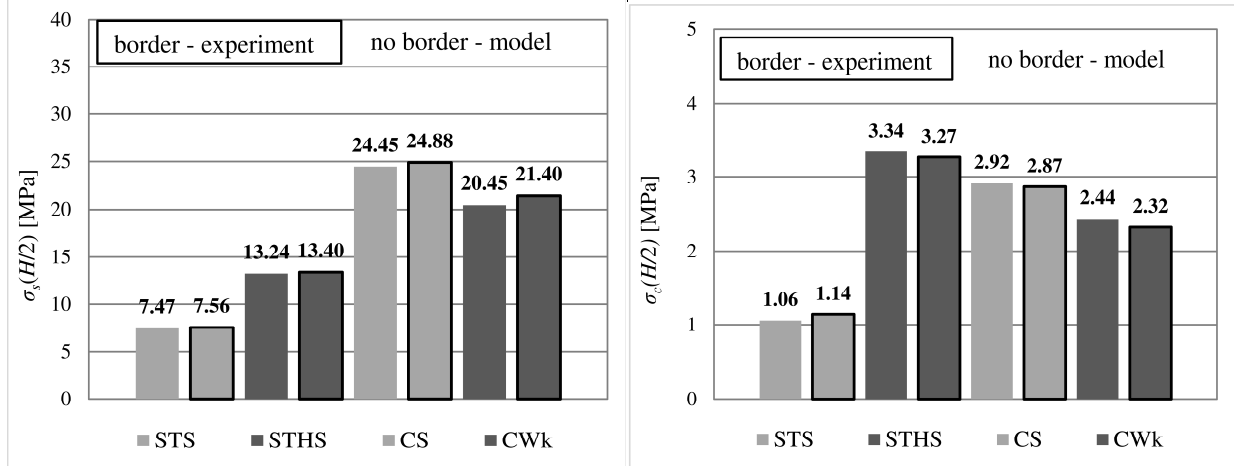

Fig. 7. Comparison of average stress in: a) steel and b) concrete in the midheigth of specimens in the ultimate limit state $N=N_{U}$

In [8] Roeder et al. concluded that the limit value of $H$, that can be used in eq. (3.10), equals to 3.5 times the diameter of the tube.This finding was based on the observation of Cameron [2] that the maximum average bond stress capacity descreases with longer lengths of push-out test specimens. Indeed if the transfer length of specimen is too large, the slip close to the loaded end may exceed the maximum value $s_{\max }$, therefore in that area the bond stress may be equal to zero (see Fig. 1b). On the other hand for long push-out specimens the slip close to the free end may still be equal to zero, therefore an exponential, not uniform, distribution of bond stress may still be present in that area. In both cases constant distribution of shear strength $\tau_{U}$ along the height of the push-out test sample is present only on its part, therefore substituting the full length of the sample into 
the eq. (3.10) results in underestimation of the shear strength $\tau_{U}$ for longer specimens.

\section{CONCLUSIONS}

In the paper two analytical models of the behaviour of steel and concrete in CFST push-out test specimens were presented. The first (full bond) model allows one to estimate the force for which the loss of adhesion begins at any given cross section, provided that the strains of steel on that particular section were measured. In the opinion of the authors the force $N_{b}$ for which the experimental results begin to deviate from the analytical full bond model can be interpreted as the force for which the loss of adhesion begins. Moreover if the number of strain gauges placed along the height of the push out test specimen is large enough, the distribution of the shear stress at the interface between the materials can be computed using equilibrium eqs. (3.11).

Furthermore the perfectly plastic model was derived assuming that the shear stress distribution along the height of the push-out test specimen is constant. This assumption is valid for the maximum load $N=N_{U}$ provided that the height of a sample is not too high in relation to its transverse dimensions. According to the presented model the stress distribution in steel and concrete is triangular in shape. Based on the strain readings of strain gauges placed in the middle of specimens the stress in steel and concrete was computed and compared with model predictions. It was found that there is a very good agreement of the results what confirms the validity of the assumptions made in the analysis that the distribution of the bond stress at the transfer length is constant for $N=N_{U}$ for all tested specimens. Both models can be used to better understand the mechanisms of interaction between steel and concrete in composite steel-concrete columns and to validate constitutive models of shear stress - slip $(\tau-s)$ behaviour that can be used in more sophisticated numerical analyses.

\section{REFERENCES}

1. Burak, E., Tuncan A.: Determination of frictional behavior between concrete and steel tube interaction, Proceedings of the 7th European Conference on Steel and Composite Structures Eurosteel, 521-522, Italy, 2014.

2. Cameron, B.: Bond behavior in concrete filled tube composite

3. columns, Ms thesis, University of Washington, Seattle, 1997.

4. EN 1994-1-1 Eurocode 4: Design of composite steel and concrete structures. Part1-1: General rules and rules for buildings, 2004.

5. Hunaiti, Y.M.: Bond strength in battened composite columns, Journal of Structural Engineering, 117, 3 (1991) 699-714. 
6. Hunaiti, Y.M.: Aging effect on bond strength in composite sections, Journal of Materials in Civil Engineering, 6, 4 (1994) 469-73.

7. Ke, X.J., Sun, Y.H., Yang, Z.: Calculation on Bond Strength of High-Strength Concrete Filled Steel Tube, Proceedings of the 4th International Conference on Sensors, Measurement and Intellgent Materials, 995-999, China, 2016.

8. Khodaie, N.: Effect of the Concrete Strength on the Concrete-Steel Bond in Concrete Filled Steel Tubes, Journal of the Persian Gulf, 4, 11 (2013) 9-16.

9. Roeder, C.W., Cameron, B., Brown, C.B.: Composite action in concrete filled tubes, Journal of Structural Engineering, 125, 5 (1999) 477-484.

10. Szmigiera, E., Woyciechowski, P.: Influence of the compaction method on the bond between steel and concrete in composite columns, Periodica Polytechnica-Civil Engineering, 57, 2 (2013) 129-137.

11. Szmigiera, E., Woyciechowski, P., Szadkowska, M.: Badania przyczepności betonu do stali konstrukcyjnej w stupach zespolonych, in: Beton i Konstrukcje $\mathrm{z}$ betonu-badania, Seria Monografie Zakładu Konstrukcji Betonowych i Zakładu Inżynierii Materiałów Budowlanych 2015, 111-127.

12. Virdi, K.S., Dowling, P.J.: Bond strength in concrete filled circular steel

13. tubes.Compositecolumns, CESLIC Report, CC11, Engineering Structures Laboratories, 1975.

14. Virdi, K.S., Dowling, P.J.: Bond strength in concrete filled steel tubes, IABSE Proceedings, P-33/80:125-39, 1980.

\section{ANALIZA NAPRĘŻEŃ W BETONIE I STALI W ELEMENTACH CFST PODDANYCH BADANIU PUSH-OUT}

\section{Streszczenie}

W pracy zaprezentowano analizę naprężeń w stali i betonie samozagęszczalnym w zespolonych elementach CFST poddanych badaniu przyczepności materiałów za pomocą testu push-out. Przedstawiono dwa modele obliczeniowe pozwalające na analizę stanu naprężeń na podstawie odczytów odkształceń stali w początkowej fazie badania oraz w momencie uzyskania maksymalnej siły. Przyczepność stali do betonu w początkowej fazie zapewniana jest przez zjawisko adhezji - do osiągnięcia pewnej wartości siły nie występuje poślizg między materiałami co powoduje ich pełne zespolenie. W pierwszym modelu założono pełne zespolenie obu materiałów a siła, dla której przewidywania modelu zaczynają odbiegać od wyników badań doświadczalnych może być, zdaniem autorów, uznana za siłę, przy której następuje utrata adhezji w danym przekroju. Za pomocą drugiego modelu obliczeniowego przeprowadzono analizę rozkładu naprężeń normalnych w stali i betonie jaki występuje przy maksymalnej sile działającej na elementy badawcze. Zakładając, że naprężenia ścinające między 
materiałami są stałe na wysokości elementu, na podstawie równań równowagi stwierdzono, że rozkład naprężeń w obydwu materiałach ma kształt trójkątny na długości strefy kontaktu. Przewidywania modelu z bardzo dobrą zgodnością potwierdzają odczyty odkształceń tensometrów umieszczonych w środku wysokości elementów. Zaprezentowane $\mathrm{w}$ pracy analityczno-doświadczalne metody analizy stanu naprężenia $\mathrm{w}$ elementach zespolonych mogą posłużyć do wyznaczania parametrów związków konstytutywnych „naprężenie przyczepności - poślizg” oraz walidacji modeli numerycznych.

Słowa kluczowe: elementy zespolone stalowo-betonowe, CFST, naprężenia przeczepności, adhezja, test push-out

Editor received the manuscript: 27.06 .2017 